\title{
Experimental Investigation of Natural Fiber with Epoxy Resin
}

\author{
Laxmikant D. Joshi, Amar A. Rajgole, Rahul Hiremath, Sachin Khomane
}

\begin{abstract}
This paper aims study of natural fiber composites bonded with epoxy resin. The natural fibers are used banana and sisal as material for the fabrication of laminating board. The laminated boards were fabricated by wooden mould fiber stitching method. Twice chemically treated fibers showed good results in flexural strength.

For the orientations such as 0-90 and 45-45 gives better results for Flexural strength as well as for tensile strength. By increasing layers one can increase flexural and tensile strength.
\end{abstract}

Index Terms- Sisal fiber, Banana fiber, Natural Fiber Composites.

\section{INTRODUCTION}

Since from last decades, natural fiber composites have received attention as the alternative for synthetic ones both from study as well as industries world.Fiber like Banana which is waste product of Banana and sisal fibers were used as increasing reinforcement materials with epoxy resin as binder for fabrication of laminates. Orientations such as 0-90 and 45-45 were used for preparation and after fabrication samples tested for tensile as well as for flexural strength.

Badrinath et al. [1] in this work, sisal and banana fiber have been used as a reinforcement material to rise in effectiveness of natural fibers. The laminate is fabricated by hand lay-up method and testing carried out such as tensile, flexural and water absorption.

Baharin et al.[2] said that from the banana stem and leaf laminated boards were produced. Tensile strength and impact strength and elastic modulus increases with increase in numbers of layer, and showed that the properties measured along the fiber orientation were higher than in the perpendicular direction.

Elenchezhian et al. [3] Paper aims at learning mechanical properties of fiber composites. Gives review on the mechanical properties of Abaca, Jute, Sisal fibers etc.

Ramdan et al. [4] said that short term test of durability on hemp concrete cylinders made up of one layer of hemp fiber bundles were conducted to study its behavior and on other hand a suitable protected configuration coating is provided

Laxmikant D. Joshi, UG Student, Mechanical Engineering Department, SVERI's College of Engineering, Pandharpur, Maharashtra, India, Amar A. Rajgole,UG Student, Mechanical Engineering Department, SVERI's College of Engineering, Pandharpur, Maharashtra, India,

Rahul D. Hiremath, UG Student,, Mechanical Engineering Department, SVERI's College of Engineering, Pandharpur, Maharashtra, India Sachin M. Khomane, Assistant professor, Mechanical Engineering Department, SVERI's College of Engineering, Pandharpur, Maharashtra, India by epoxy.

Jordan et al.[5] Aims study of two different chemicals to promote the bonding between fibers and matrix such as LDPE .Untreated banana fibers gives measurable increase in composites properties.

Kikuchi et al. [6] Said that by using spray up molding technique jute fiber was used to fabricate ecologically friendly composites. Spray up molding equipment is very flexible so it can make various composites easily.

Ramesh et al. [7] this paper aims that natural sources provide indisputable advantages over synthetic material as low cost, non toxicand, minimum waste disposal problems. Samples with different fiber were fabricated by using hand layup method.

Dixit et al. [8] this paper proposed that availability of natural fibers at low cost and ease of manufacturing and having great attention of researchers towards possibilities of reinforcement. Chemically treated natural fibers shows better results in impact, fatigue strength.

Rajesh et al. [9] aims that natural fiber biodegradable composites were prepared with short jute fiber as a reinforcement and PLA as a matrix. Tensile properties shows that the successive treated fiber at higher fiber loading were better than those of composites with untreated fibers.

So, by studying all work done by researchers on natural fiber, laminated boards were prepared by hand layup method. That's why there is scope to work on methodology of fabrication of laminating boards with another method. This paper aims fabrication of laminating boards by using wooden mold fiber stitching method.

\section{Methodology}

\section{A. Selection of Best Natural Fiber.}

There are number of natural fibers in the world which are named as natural fiber composites.Some of them are having very good reinforcement property as well as mechanical properties. For our laminate preparation selectedfiberssuch as Sisal and Banana natural fibers which are having good mechanical properties. These fibers are also easily available in surrounding areas, having very low cost with good properties.

\section{B. Bleaching/Chemical Treatment}

For removing lignin present over the fiberas well as for improving strength of fibers it very essentials that bleaching treatment is very necessary.For chemical treatment alkali with sodium hydroxide and Peroxide treatment were selected.In these fibers are effectively treated with 5\% by weight $\mathrm{NaOh}$ solution for one day and then washed by distilled water. After this process is again repeated for 
peroxide treatment, and finally fibers were dried in sun light. Fig. 1 shows chemical treatment.

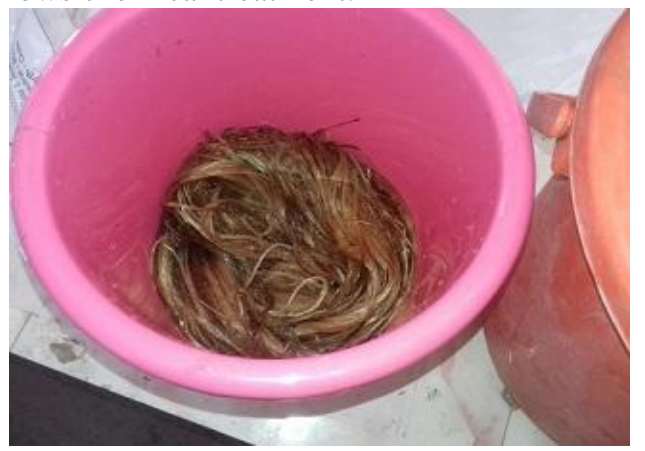

Fig.1 Chemical Treatement

\section{Extraction of bleached fibers}

After chemical treatment next step was the extraction of treated natural fibers for separationpurpose. This extraction is done by using hand. Separated all banana as well as sisal fibers in single fibers as shown in fig. 2.

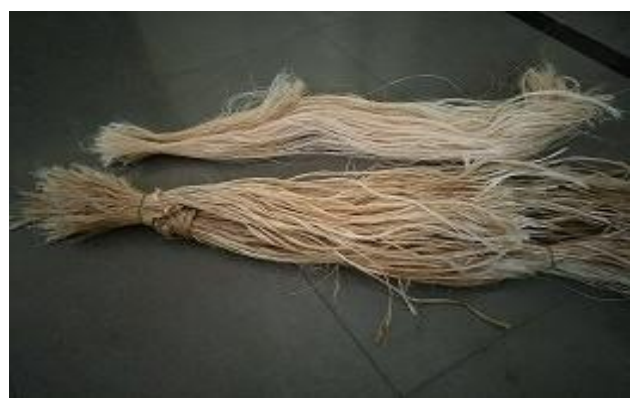

Fig.2 Extraction of fibers

\section{Preparationof Wooden Would.}

Up till now the laminate of natural fibers were prepared using hand-lap method only. But for our work a wooden mold fiber stitching method was used. On the upper side of a mold small nails were inserted for the purpose of stitching of fibers sisal and banana respectively. Fig. 3 shows wooden mold.

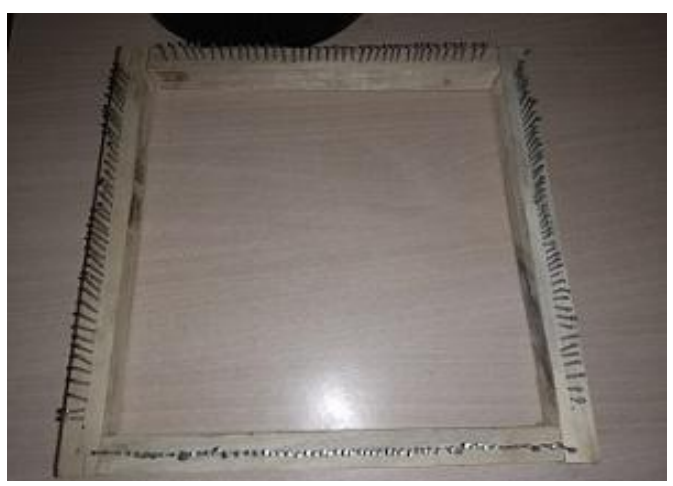

Fig.3 Wooden Mould

\section{E. Fabrication Of Laminate}

After the preparation the wooden mould next step was preparation of the laminate by using epoxy resin having grade as LY556 and HY917 as Araldite and hardenerrespectively.
Orientation such as 0-90 (degree) and 45-45 (degree) taken for two plates respectively. Fibers were attached to mould by using of nails of mould. After one $0^{\circ}$ layer there is layer of $90^{\circ}$ .After all finishing of layers, epoxy wasapplied as combination of araldite and hardener(epoxy resin) over layers. Someweight is put over the plate so that it will be in uniform thickness, and After $8 \mathrm{hrs}$ plate wasready. With the similar fashion another laminate was made having orientation as 45-45 (degrees) orientation.

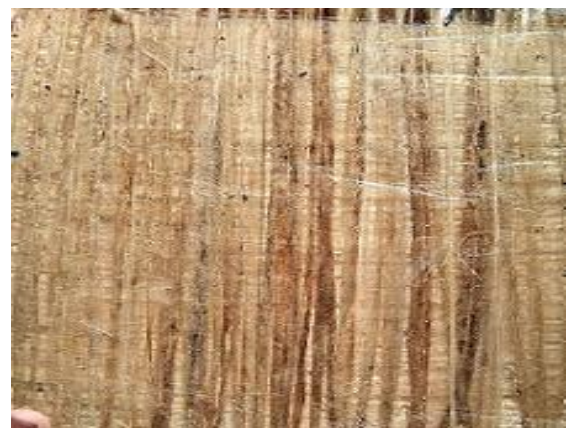

Fig. $40^{0}-90^{0}$ Fabricated Laminate

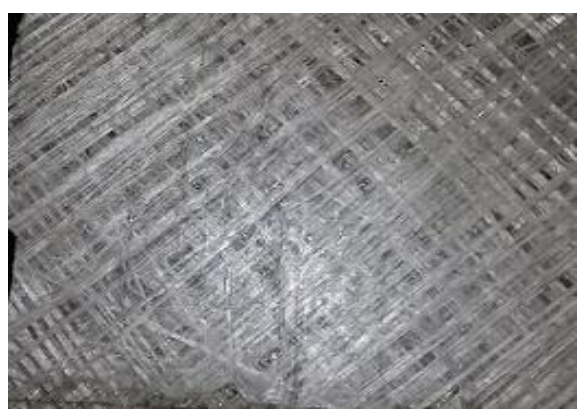

Fig. $545^{0}-45^{0}$ Fabricated Laminate

Figurs numbers 4 and 5 show the fabricated laminating boards for $0^{0}-90^{\circ}$ and $45^{\circ}-45^{\circ}$ orientations, respecively.

\section{F. Testing of laminate.}

On the prepared laminating plate tensile test and flexural test were taken for analyzing its behavior under loading conditions. Tensile test is carried out under ASTM D638-2003 for this tensile test, specimen was made as dumbbellshape and for flexural test specimen is made according to ASTM D790-2003.Following fig no. 6 shows prepared specimens for testing.

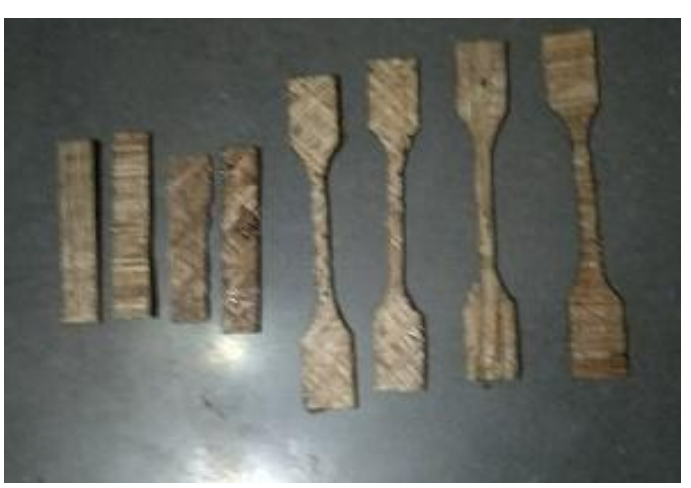

Fig.6 Tensile and Flexural Specimen. 


\section{RESULTS AND DisCUSSION}

As mentioned above testing of laminate were taken as Tensile as per ASTM D 638-2003 and ASTM D 790-2003 for flexural respectively. Following figures shows behavior of specimens under loading conditions.

\section{A. Sisal-banana $\left(0^{\circ}-90^{\circ}\right)$ orientation.}

3. 1. 1Tensile test:-

Tensile test graph for sample no. 1 and 2 are shown in fig. no 7 and 8 , respectively.

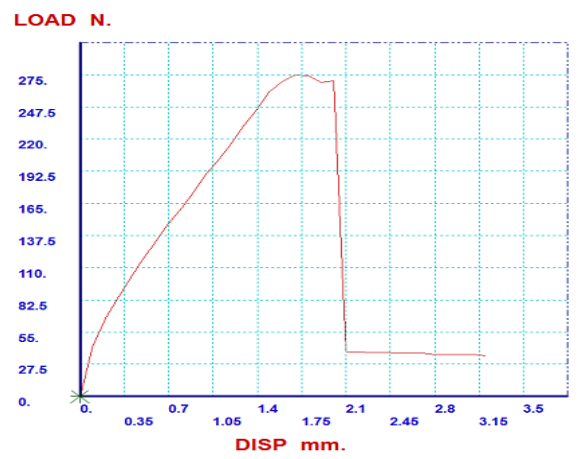

Fig.7 Load vs. displacement for tensile test.

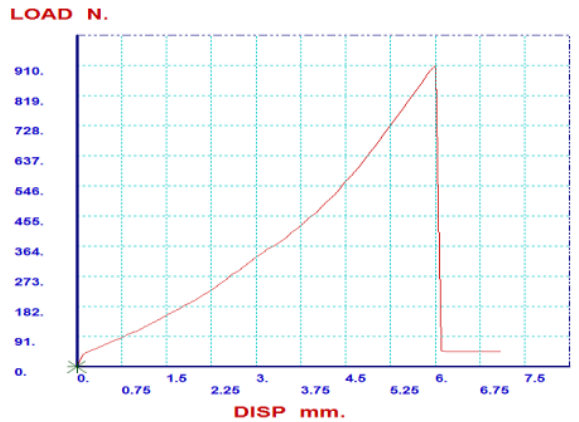

Fig. 8 Load vs. displacement for tensile test.

For tensile test load cell is $980 \mathrm{~N}$, speed is $10 \mathrm{~mm} / \mathrm{min}$, and tensile strength is $21.123 \mathrm{MPa}$ and $66.250 \mathrm{MPa}$ respectively.

3.1.2 Flexural Test:-

Flexural test graph for sample no. 2 are shown in fig no 9 and 10 , respectively.

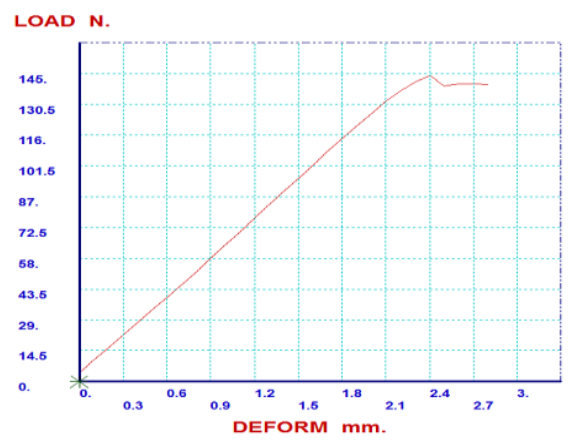

Fig. 9 Load vs. displacement for flexural test.

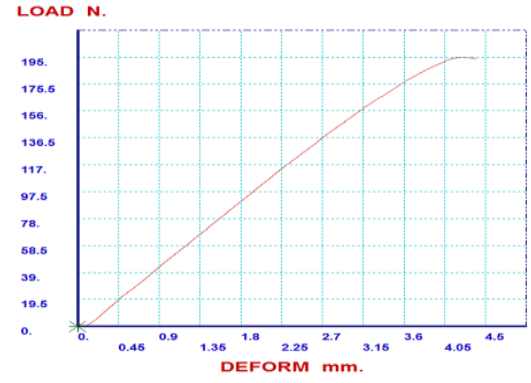

Fig. 10 Load vs. displacement for flexural test.

For flexural test, speed id $5 \mathrm{~mm} / \mathrm{min}$, load cell is $980 \mathrm{~N}$, peak load is $143.864 \mathrm{~N}$ and Flex strength is $61.594 \mathrm{MPa}$ and 84.181 MPa, respectively.

\section{B. Sisal- banana $\left(45^{\circ}-45^{\circ}\right)$ orientation.}

a. Tensile Test:-

Ttensile test graph for sample no. 1 and 2 are shown in fig. 11 and 12 , respectively.

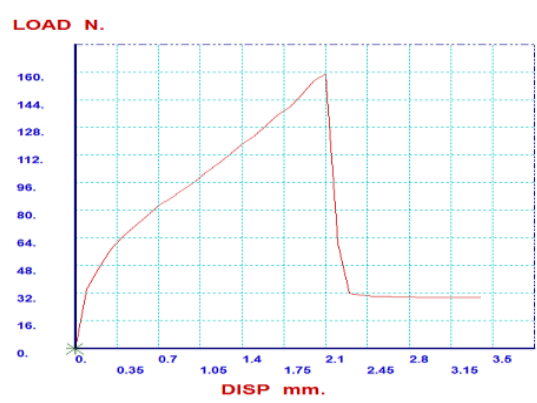

Fig. 11 Load vs. displacement for tensile test.

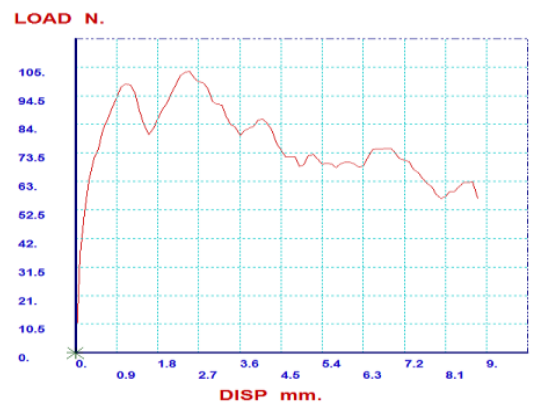

Fig. 12 Load vs. displacement for flexural test

For tensile test load cell is $980 \mathrm{~N}$, speed is $10 \mathrm{~mm} / \mathrm{min}$, max load is $158.956 \mathrm{~N}$ and tensile strength is $26.58 \mathrm{MPa}$ and 14.77 $\mathrm{MPa}$ respectively.

b. Flexural Test:-

Flexural test graph for samples 1 and 2 shown in fig. 13 and 14 , respectively. 


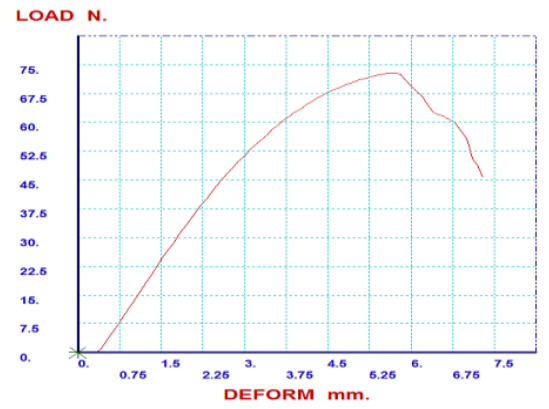

Fig .13 Load vs. displacement for flexural test.

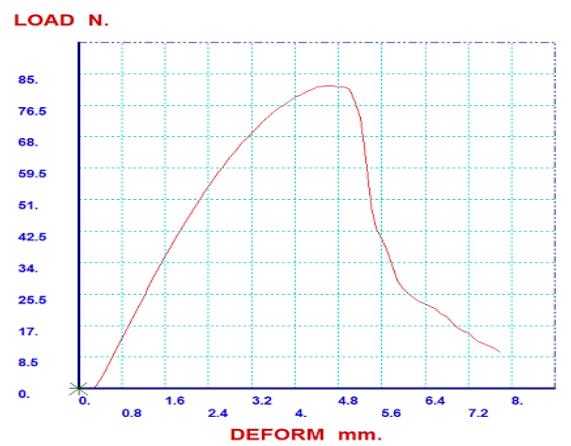

Fig. 14 Load vs. displacement flexural test.

For flexural test of specimen having orientation as $45^{\circ}-45^{0}$ samples load cell is $980 \mathrm{~N}$, Speed is $5 \mathrm{~mm} / \mathrm{min}$, peak load is $72.814 \mathrm{~N}$, Flexural strength for both samples are $48.10 \mathrm{MPa}$ and 48.022 Mpa respectively.

Table 1 shows tabulated results for all testing such as Tensile and flexural test for $0^{0}-90^{\circ}$ and $45^{\circ}-45^{\circ}$ orientations.

Table no. 1 Tabulated Results of Tests.

\begin{tabular}{|l|l|l|l|l|}
\hline No. & \multicolumn{2}{|c|}{ Sample no. } & $\begin{array}{l}\text { Tensile } \\
\text { Strength } \\
(\mathrm{MPa})\end{array}$ & $\begin{array}{l}\text { Flexural } \\
\text { Strength } \\
(\mathrm{MPa})\end{array}$ \\
\hline \multirow{2}{*}{1} & $0^{0}-90^{0}$ & No. 1 & 21.12 & 64.59 \\
\cline { 2 - 5 } & $0^{0}-90^{0}$ & No. 2 & 66.25 & 84.18 \\
\hline \multirow{2}{*}{2} & $45^{0}-45^{0}$ & No. 1 & 26.58 & 48.10 \\
\cline { 2 - 5 } & $45^{0}-45^{0}$ & No. 2 & 14.77 & 48.02 \\
\hline
\end{tabular}

By referring Table no. 1 following conclusions taken as for orientations $45^{\circ}-45^{\circ}$ and $0^{\circ}-90^{\circ}$ material behavior is good for Flexural test as compared to Tensile test.

\section{CONCLUSION}

The experimental Investigation of natural fiber with epoxy resin shows better result for new fabrication method as wooden mold fiber stitching method. This method also gives good orientation for laminate fabrication. Following conclusion taken from the result analysis as ,

- The flexural test shows better result for $0^{0}-90^{0}$ orientation.

- The tensile test is giving good result for $0^{0}-90^{0}$ orientation.

\section{ACKNOWLEDGEMENT}

Authors sincerely thanks to Principal Dr. B. P. Ronge, Mr. S. R. Gavali, Head of Mechanical engineering and mentor Mr.

S. M. Khomane, assistant professor , SVERI's college of Engineering Pandharpur, for supporting and guiding.

\section{REFERENCES}

[1] Baharin, A., Fattah, N.A., Bakar, A.A. and Ariff, Z.M., 2016. Production of laminated natural fibre board from banana tree wastes. Procedia Chemistry, 19, pp.999-1006.

[2] Badrinath, R. and Senthilvelan, T., 2014. Comparative investigation on mechanical properties of banana and sisal reinforced polymer based composites. Procedia materials science, 5, pp.2263-2272.

[3] Elanchezhian, C., Ramnath, B.V., Ramakrishnan, G., Rajendrakumar, M., Naveenkumar, V. and Saravanakumar, M.K., 2018. Review on mechanical properties of natural fiber composites. Materials Today: Proceedings, 5(1), pp.1785-1790.

[4] Ramadan, R., Saad, G., Awwad, E., Khatib, H. and Mabsout, M., 2017. Short-Term Durability of Hemp Fibers. Procedia Engineering, 200, pp.120-127.

[5] Jordan, W. and Chester, P., 2017. Improving the properties of banana fiber reinforced polymeric composites by treating the fibers. Procedia engineering, 200, pp.283-289.

[6] Kikuchi, T., Tani, Y., Takai, Y., Goto, A. and Hamada, H., 2014 Mechanical Properties of Jute Composite by Spray up Fabrication Method. Energy Procedia, 56, pp.289-297.

[7] Ramesh, M., Atreya, T.S.A., Aswin, U.S., Eashwar, H. and Deepa, C., 2014. Processing and mechanical property evaluation of banana fiber reinforced polymer composites. Procedia Engineering, 97, pp.563-572.

[8] Dixit, S., Goel, R., Dubey, A., Shivhare, P.R. and Bhalavi, T., 2017. Natural fibre reinforced polymer composite materials-a review. Polymers from renewable resources, 8(2), pp.71-78.

[9] Rajesh, G. and Prasad, A.V.R., 2014. Tensile properties of successive alkali treated short jute fiber reinforced PLA composites. Procedia Materials Science, 5, pp.2188-2196.

[10] Węcławski, B.T., Fan, M. and Hui, D., 2014. Compressive behaviour of natural fibre composite. Composites Part B: Engineering, 67, pp.183-191. 